\title{
Obituary
}

\section{Peter Brian Coaker (23 June 1928 - 23 June 2005)}

Looking down the list of Presidents of the Mathematical Association, Peter Coaker stands out for one very significant reason. The central location for his working life was neither academe nor the schools but industry. His qualifications on the Presidents' honours board at the Association's headquarters are listed as BSc, ARCS, DIC, FIMA, FBCS. The length and breadth of these qualifications, spanning the fields of mathematics, meteorology (a Diploma of Imperial College) and computing, are also exceptional for a President of the Association.

Peter was born in Chingford on 23 June 1928 and attended three different schools in Chingford before moving in 1942 to Tiffin Boys' School, Kingston upon Thames, where he completed his secondary education in 1946. Moving on to higher education, he qualified with a First Class in Mathematics both in the Associateship of the Royal College of Science (1948) and the London University BSc (Special Honours, 1949), alongside the DIC (1949).

Peter started his working life in 1949, perhaps surprisingly acting first as an assistant chemist for the Anglo-Iranian Oil Company, based in the Research Centre at Sunbury. He was to remain with this Company, which became the British Petroleum (BP) Company in the mid-1950s, for nearly thirty-five years up to his retirement. He served BP in a wide range of roles in research, development, training and external relations: research in mathematics, physics and statistics at Sunbury in the 1950s; operational research and computing in the 1960s; co-ordination of research and development in the 1970s; and, increasingly, educational affairs up to his retirement in 1983.

In educational circles, Peter was quick to point out on many occasions that he was not a teacher but an industrial mathematician. However, the roots of his interest in educational affairs go back at least to the time of his National Service in the RAF from 1950 to 1952. Here, after just four weeks orientation for Education Officers, Peter had to rise to the challenge of teaching mathematics and radio (an unfamiliar subject for Peter) to apprentices at Cranwell.

In relation to the development of mathematics education, the roots of Peter's involvement go back to 1960, when he moved from research at Sunbury to the main London office of BP. From this time he came increasingly to play a key role as a catalyst for and facilitator of mathematics curriculum developments, linking the subject to its wideranging applications, particularly in industry. This involvement grew in 1961 through a major Conference on 'Mathematics in Education and Industry' (MEI), sponsored by BP, and involving industrialists, university staff and schoolteachers. Steven Mullaly, a personnel manager at BP, was a prime mover in this important initiative, working with Theodore Combridge (Association President), who acted as chairman. As a young mathematician 
in the OR division, Peter attended and contributed on the applications of linear programming in the oil industry. Both Mullaly and Combridge were important influences on Peter's subsequent educational work.

The seminal 1961 Conference led to the establishment of the Schools and Industry Committee of the Mathematical Association, initially supported by some BP funding, and to the development of industrial and commercial placements for school teachers, to promote potential links between mathematics, its applications, and school teaching. These placements and schoolteacher fellowships led also to the development of new MEI syllabuses as part of the MEI North London Schools' Project. Peter provided early encouragement and support for these initiatives, and, in particular, BP provided batch processing for punched cards in pioneering school mathematics work involving computers and new numerical methods.

In parallel with the early developments associated with MEI and the schools, university and industrial mathematicians were also working towards the creation in 1964 of a new Institute for Mathematics and its Applications. Theodore Combridge was again a prime mover and he also supported Peter's application to become a founder member as an Associate Fellow. In 1980 Peter transferred to a full fellowship of the IMA.

Peter joined the Mathematical Association in 1967 and, up to 1985 (in his Presidential year), he missed only one Annual Conference. He chaired the Schools and Industry Committee, 1980-90, and acted as an executive for the Teaching Committee over the same period. He served on the Council as a Vice-President, 1985-1993. Fittingly, in 1981 he chose the title 'Why teach mathematics?' for his Presidential address to the London branch of the Association. In the following year, the Cockcroft Report, Mathematics Counts, adopted the same title for its opening chapter, which highlighted the usefulness of mathematics 'as a powerful means of communication' as the principal justification for teaching the subject. In 1985, Peter expanded on this same theme in his Presidential address at the Annual Conference in Dundee.

In the 1970s and 1980s, apart from his work for the Association, Peter served on or chaired numerous committees and other groups involving a wide range of bodies and educational interests. In addition to his steering work for BP Schoolteacher Fellowships, this work included: examinations in higher education for the CNAA, the International Baccalaureat, and school examinations for the Universities of London and Cambridge; two examinations watchdogs, the Secondary Examinations Council and the School Examinations and Assessment Council; advisory work for individual higher education institutions; Royal Institution Mathematics Masterclasses; various Schools Council committees; and educational work involving the CBI. Within BP, this growing and varied educational involvement was recognised by Peter's formal appointment in 1978 as an Education Division Manager within the Personnel Department; in 1980 he adopted the new title of Education Affairs Manager up to his retirement.

It is particularly appropriate that in the year of his retirement from BP, 
1983, a book was published, titled Maths at Work. It was edited by Geoffrey Howson and Ron McLone and published by Heinemann Educational Books. Peter was again involved behind the scenes, providing encouragement and BP funding for an associated lecture series - linked with Association branches - on the wide-ranging uses of mathematics in commerce, industry and elsewhere.

Following his early retirement from BP, he moved with his wife and son down to Exford, in Somerset, where he settled for over twenty years, whilst still continuing his active involvement in mathematics education up to 1993. He died in 2005 on the same date as his birth, 23 June. It is fitting to conclude with a personal tribute from Bertie Bellis (Association President 1971-1972) of the MEI Schools' Project:

'... he was on the scene when mathematics teaching was beginning to change, and he was able to highlight the importance of the subject in a vast variety of applications. He was an excellent communicator as well as being an enthusiast, and he encouraged those of us who were teaching to take on ideas which might otherwise have been overlooked. His easy manner and attractive personality made him an ideal ambassador ...'

Peter's contribution to mathematics education was indeed exceptional and outstanding.

MICHAEL H. PRICE

University of Leicester, School of Education, 21 University Road, Leicester LEI TRF 